\title{
Suomalaisten maatilojen rahoitusriskit ja niihin vaikuttavat tekijät
}

\author{
Perttu Pyykkönen ${ }^{1)}$, Tapani Yrjölä²) ja Arto Latukka ${ }^{3)}$ \\ ${ }^{1)}$ Pellervon taloudellinen tutkimuslaitos PTT, Eerikinkatu 28, 00180 Helsinki, perttu.pyykkonen@ptt.fi \\ ${ }^{2)}$ Pellervon taloudellinen tutkimuslaitos PTT, Eerikinkatu 28, 00180 Helsinki, tapani.yrjola@ptt.fi \\ ${ }^{3)}$ MTT Taloustutkimus, Luutnantintie 13, 00410 Helsinki, arto.latukka@mtt.fi
}

\section{Tiivistelmä}

Maatalouden investointien keskimääräinen koko on kasvanut selvästi koko EU-jäsenyyden ajan. Myös maatalouden velat ovat kasvaneet ja keskittyneet yhä pienemmälle osalle maatiloista. Rahoitusriskien tarkempi huomioon ottaminen on siten tärkeää. Tiukempaan riskiluokitukseen ohjaa myös kansainvälisen Baselin pankkivalvontakomitean uudet, vuonna 2007 voimaan tulleet säännökset, joihin sisältyy velvollisuus luokitella luottolaitoksen asiakkaat riskiluokkiin.

Suomessa maatalouden luototuksessa pääpaino on tähän saakka ollut vakuuksien riittävyydessä. Nyt maksukyvyn merkitys riskiluokituksessa kasvaa. Maatalouden rahoitusriskien analysoinnille on siten sekä sisäisiä että ulkoisia syitä.

Tässä tutkimuksessa selvitetään, mitkä maatalouteen liittyvät tekijät vaikuttavat rahoitusriskeihin ja niiden mahdolliseen kasvuun. Näiden tekijöiden tunnistaminen edesauttaa paitsi rahoitusriskien hallintaa myös riskiluokitusjärjestelmien kehittämistä. Lisäksi tulokset ovat avuksi uusien investointitukijärjestelmien kehittämisessä ja suunnittelussa.

Tutkimusaineistona käytetään niiden 644 MTT Taloustutkimuksen kirjanpitotilan tietoja, jotka ovat olleet mukana sekä vuonna 2000 että vuonna 2005. Tiloille lasketaan rahoitusriskin suuruutta kuvaava riskiluokkatekijä (credit score), jossa otetaan huomioon tilan kannattavuuskerroin, maatalousvelkojen takaisinmaksuaika, omavaraisuusaste ja yrittäjätuloprosentti. Nämä viimeksi mainitut osatekijät (credit sub score) normeerataan ja yhdistetään painottamalla niitä eri painoilla em. riskiluokkatekijäksi. Tilat jaettiin riskiluokkatekijän perusteella kumpanakin tutkimusvuonna samoin perustein määriteltyihin kymmeneen riskiluokkaan. Tulokset osoittavat, että keskimääräinen riskiluokka on heikentynyt tarkastelujaksolla eli rahoitusriskit ovat kasvaneet.

Ekonometrisellä analyysillä selvitettiin tarkemmin riskiluokkatekijään vaikuttavia tekijöitä. Tilakohtaisista tekijöistä voimakkaimmin luottoriskiä kasvattaa velkojen määrän lisääntyminen. Lisäksi luottoriskit ovat viljatiloilla olleet kotieläintiloja suurempia. Tämä johtuu viljan hintojen laskusta seuranneesta negatiivisesta kannattavuuskehityksestä. Luottokelpoisuus on myös heikentynyt ajan myötä, joka selittynee pääosin tuotantopanosten hintojen tuottajahintoja nopeammalla nousulla.

Tilakoon kasvattaminen (sekä pinta-alalla että rakennus- ja konepääoman määrällä mitaten) puolestaan parantaa tilan rahoitusasemaa kasvavien tulojen, paremman kannattavuuden ja lisääntyvien vakuuksien myötä. Myös tilan keskisadolla on positiivinen vaikutus rahoitusriskien vähenemiseen. Tämä muuttuja heijastelee ainakin osittain tuottajan ammattitaitoa.

Vaikka rahoitusriskit ovat kasvaneet, ei vakavissa taloudellisissa vaikeuksissa olevien tilojen määrä ole juurikaan kasvanut. Jos kehityssuunta ei kuitenkaan muutu, rahoitusriskien lisääntyminen tuo mukanaan merkittäviä haasteita niin maataloudelle kuin sitä luotottaville pankeillekin.

Asiasanat: Rakennekehitys, rahoitus, riski 


\section{Johdanto}

Maatalouden rakennekehitys on ollut Suomessa voimakasta jo pitkään. Sinänsä EU-jäsenyys ei kovin suuresti vaikuttanut tilamäärän vähenemiseen, mutta maatalouden investoinneissa muutos on ollut selvä. Tämä johtuu jäsenyyden mukanaan tuomasta paineesta kuroa pienestä tilakoostamme johtuvaa rakenteellista haittaa umpeen lähimpiin kilpailijamaihimme verrattuna. Kiinnikurominen on vaikeaa, mutta joka tapauksessa investointitukipolitiikassa tehtiin tietoinen ja selkeä linja muutos, jolla pyrittiin kannustamaan entistä suurempiin investointeihin. Tämä on myös näkynyt maatalouden investointien kasvuna. Maatalouden investointien kehitystä kuvaa kuvio 1.

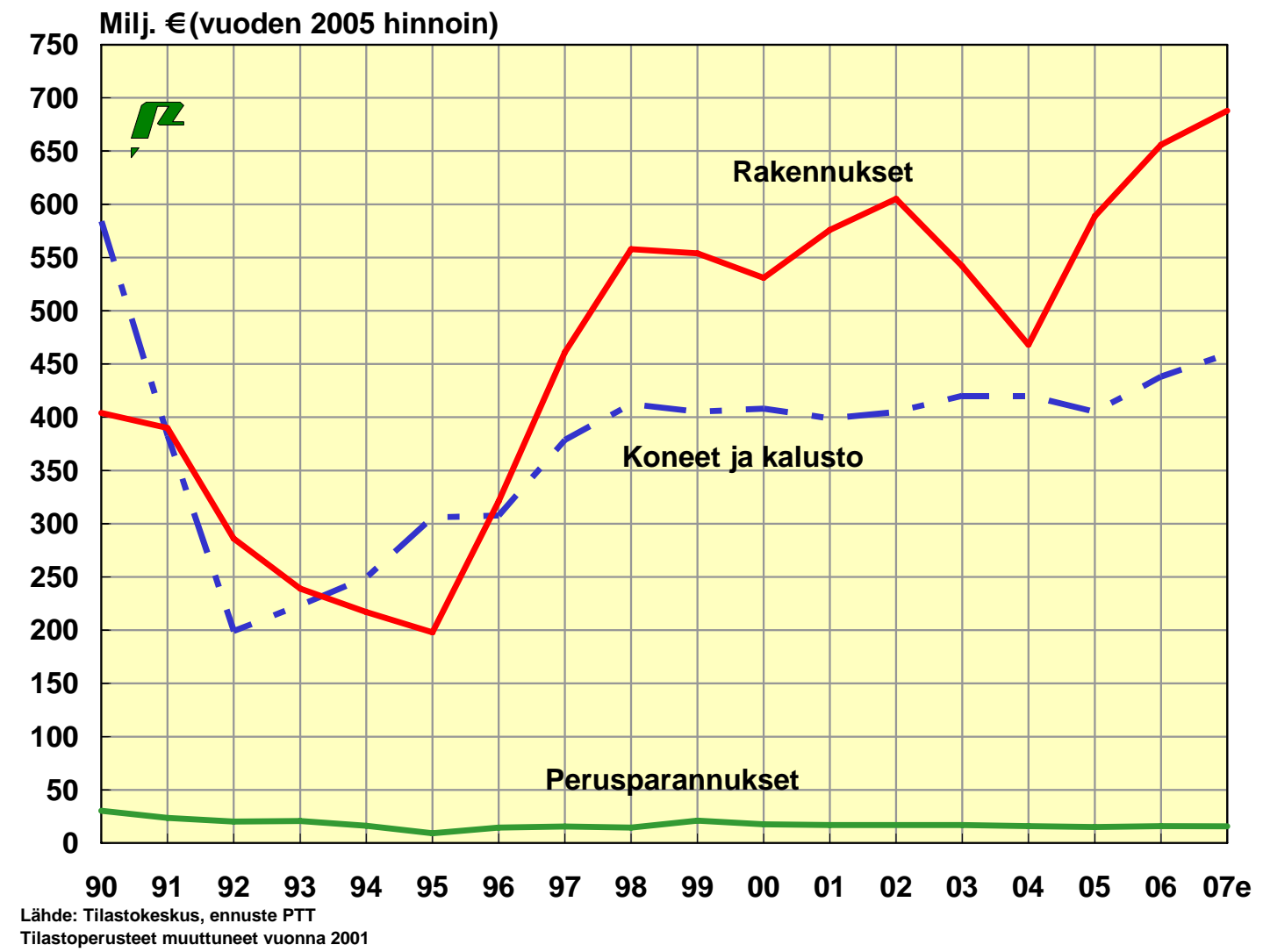

Kuvio 1. Maatalouden investoinnit 1990-2007

Koko maatalouden tasolla investoinnit vastaavat suunnilleen tuotantokapasiteetin ylläpitämiseen tarvittavia korvausinvestointeja, mutta yksittäisten tilojen investoinnit ovat olleet hyvinkin suuria. Samalla niitä on lukumääräisesti tehty vähemmän. Investointien koon kasvu näkyy selkeästi kuviosta 2.

Samalla, kun investointien keskimääräinen koko on kasvanut, myös maatalouden velat ovat kasvaneet. Näin on käynyt huolimatta siitä, että investointituki on ollut aiempaa enemmän avustuspainotteista. Investointien koon kasvu on kuitenkin merkinnyt sitä, että vieraalla pääomalla rahoitettava osuus on kasvanut. Maatalouden velat ovatkin voimakkaasti keskittyneet viimeisen vuosikymmenen aikana. Myyrän ja Pietolan (2005) tutkimuksen mukaan maatalouden velat jakautuvat huomattavasti epätasaisemmin kuin maatalouden tulot. Vuonna 2002 velkaisin 10 prosenttia viljatiloista vastasi yli 62 prosentista kaikkien viljantuotantoon erikoistuneiden tilojen veloista. Naudanlihantuotantoon erikoistuneiden tilojen joukossa velkaisin 10 prosenttia tiloista puolestaan vastasi 51 prosentista kaikkien nautatilojen veloista. Maito- ja sikatilojen keskuudessa vastaavat velkaosuudet olivat 46 ja 40 prosenttia. Edelleen heidän tutkimuksensa mukaan viidellä prosentilla viljatiloista oli vuonna 2002 velkaa yli kolme kertaa enemmän kuin niiden vuosittainen maatilatalouden liikevaihto. Muissa tuotantosuunnissa velkaisimmalla viidellä prosentilla maatiloista velat olivat maatilatalouden liikevaihtoon verrattuna yli kaksinkertaiset. 


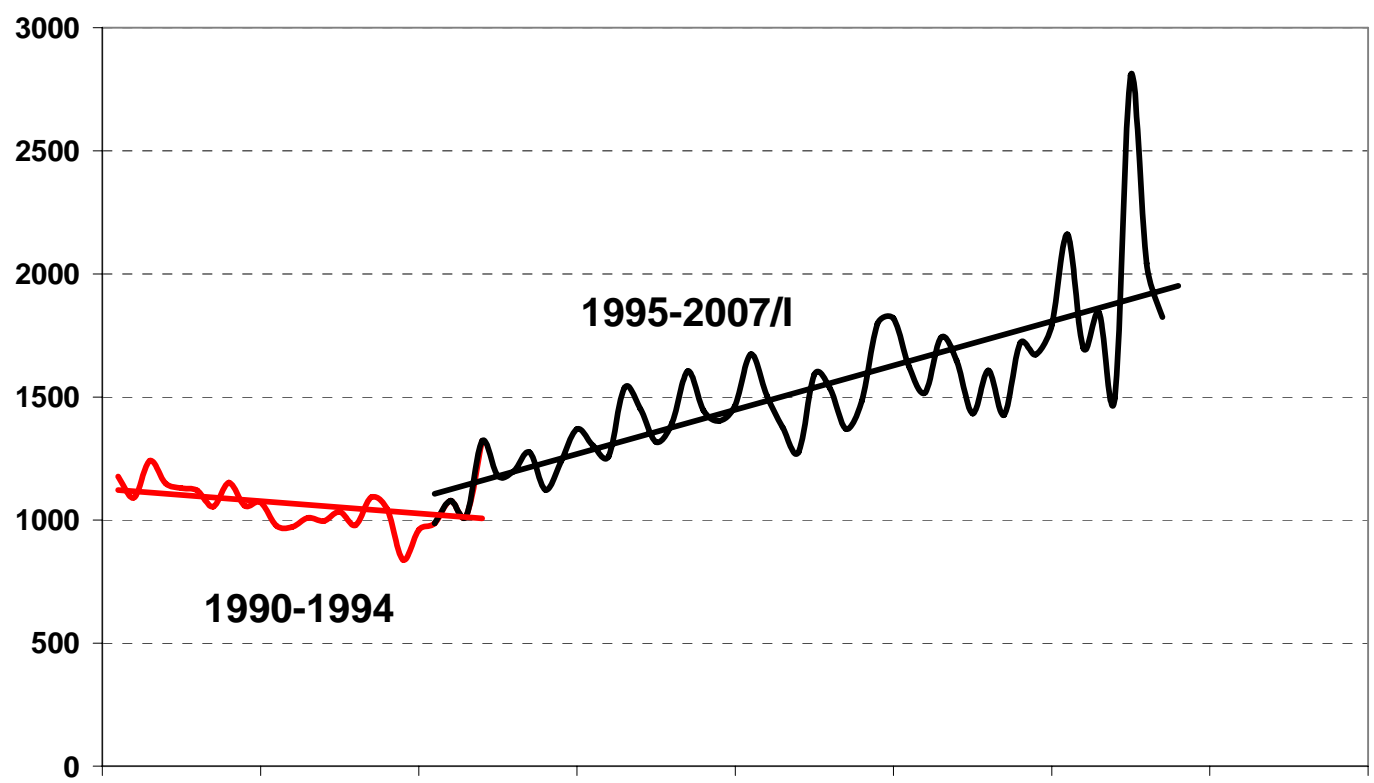

Lähde: Tilastokeskus, rakennusluvat, PTT

Kuvio 2. Maatalousrakennusten keskimääräinen tilavuus 1990-2007.

Velkojen keskittyminen merkitsee väistämättä myös rahoitusriskien kasvua. Tämä näkyy varmasti myös luotonantajien suhtautumisessa maatalouden luototukseen, vaikka luottotappiot maataloudesta ovat toistaiseksi olleetkin vähäisiä. Tiukempaan riskiluokitukseen ohjaa myös kansainvälisen Baselin pankkivalvontakomitean hyväksymät uudet säännökset (ns. Basel II sopimus), joilla kehitetään pankkien riskienhallintajärjestelmää. Tarkoituksena on nykyistä paremmin varmistaa, että pankeilla on riittävästi omaa pääomaa suhteessa niiden ottamiin riskeihin. Uudet säännökset astuvat voimaan vuonna 2007. Uusien säännösten myötä pankkien on arvioitava asiakkaidensa luottoriskit entistä tarkemmin. Tämän takia asiakkaat pitää luokitella riskiluokkiin. Mitä enemmän pankilla on riskipitoisimmissa luokissa luottoja, sitä tiukemmat ovat vakavaraisuusvaatimukset. Näin ollen asiakkaan riskiluokka vaikuttaa jatkossa myös asiakkaan luottojen marginaaliin (Walraven ja Barry 2004).

Suomessa maatalouden luototuksessa pääpaino on tähän saakka ollut vakuuksien riittävyydessä. Nyt pankkien on kehitettävä välineitä luokituksen tekemiseksi, ja todennäköisesti maksukyvyn merkitys riskiluokituksessa kasvaa. Ottaen huomioon pankkien käytettävissä olevien tietojen rajallisuus, luokitus tullee kuitenkin olemaan suhteellisen yksinkertainen.

Tutkimuksessa analysoidaan maatilojen rahoitusriskejä. Tavoitteena on selvittää, mitkä tekijät vaikuttavat rahoitusriskeihin ja niiden mahdolliseen kasvuun. Näiden tekijöiden tunnistaminen edesauttaa riskiluokitusjärjestelmän kehittämistä sekä auttaa reaalimaailmaan sovellettavissa olevien apuvälineiden löytämisessä pankkien maatalousasiakkaiden riskiluokituksen tekemiseen.

\section{Aineisto ja menetelmät}

Tutkimuksessa tehdään analyysejä, joissa tarvitaan tilatason dataa. Tätä saadaan MTT Taloustutkimuksen kirjanpitotiloilta. Tämän aineiston käyttö on perusteltua, koska suuria lainoja haettaessa voidaan olettaa, että luotonantajakin haluaa verotustietoja yksityiskohtaisempaa tietoa tilan kannattavuudesta, tuloksesta ja taseesta. Tutkimusaineistona on 644 MTT Taloustutkimuksen kirjanpitotilaa, jotka ovat olleet mukana sekä vuonna 2000 että vuonna 2005.

Suomessa maatilojen luototuksessa pääpaino on ollut vakuuksien riittävyydessä. Kiinteistökiinnitys on ollutkin hyvä vakuus. Riskiluokitukset ovat yleensä perustuneet erilaisiin pisteytysmenetelmiin (credit scoring, credit rating) (ks. Splett ym. 1994). Sitä, kuinka todennäköistä siirtyminen riskiluokasta toiseen on, ja miten luottotappioriskit realisoituvat, on tutkittu jonkin verran (mm. Zech ja Pederson 2004, Katchova ja Barry 2005). Escalante ym. (2004) puolestaan ovat selvittäneet sitä, mitkä tekijät vaikuttavat siirtymiseen riskiluokasta toiseen. He käyttivät logistista regressiomallia paneeliaineistolla analysoidessaan tilakohtaisten tekijöiden ja makrotaloudellisten tekijöiden vaikutusta 
muutokseen riskiluokituksessa. He totesivat, että amerikkalaisissa oloissa tilakohtaisten tekijöiden vaikutus riskiluokkasiirtymiin oli selvästi vähäisempi kuin makrotaloudellisten tekijöiden vaikutus.

Tässä tutkimuksessa pyritään selittämään rahoitusriskin suuruutta tilakohtaisilla tekijöillä. Jos näillä pystytään ennustamaan rahoitusriskien määrä, mallin antamia tuloksia voitaisiin myös hyödyntää riskiluokituksen tekemisessä.

Tässä tutkimuksessa lasketaan yksittäisille tiloille riskiluokkatekijä. Riskiluokkatekijä koostuu osatekijöistä (ala-arvosanat), jotka kuvaavat tilan taloutta. Osatekijöinä tässä tutkimuksessa käytetään kannattavuuskerrointa (paino 0,20), maatalousvelkojen takaisinmaksuaikaa $(0,35)$, omavaraisuusaste $(0,35)$ ja yrittäjätuloprosenttia $(0,10)$.

Riskiluokkatekijän määrittelyssä normalisoidaan osatekijät vähentämällä jokaisesta osatekijästä kyseisen osatekijän koko aineistoon perustuva keskiarvo ja jakamalla ne vastaavalla koko aineistosta lasketulla keskihajonnalla. Näin jokaisen osatekijän keskiarvoksi tulee 0 ja keskihajonnaksi 1 . Lopuksi tilan riskiluokkatekijä lasketaan painotettujen osatekijöiden summana. Riskiluokkien siirtymämatriisin muodostamiseksi tilat jaettiin riskiluokkatekijöiden perusteella sekä 2000 että 2005 samoin perustein määriteltyihin kymmeneen riskiluokkaan. Luottoriskeihin liittyvien tekijöiden analysoinnissa käytettiin ekonometristä mallinnusta.

\section{Tulokset ja tulosten tarkastelu}

Keskimääräinen riskiluokka oli vuonna 2000 6,80 ja vuonna 2005 se oli laskenut 6,44:ään eli riskit olivat kasvaneet. Kun vuonna 2000 kolmeen suurinta riskiä osoittavaan riskiluokkaan 1-3 sijoittui 3,2 \% tiloista ja riskiluokkiin 1-4 noin 8,7 \% tiloista, vuonna 2005 vastaavat luvut olivat 4,1 \% ja $11,7 \%$. Samoin vuonna 2000 kolmeen alhaisinta riskiä osoittavaan riskiluokkaan (luokat 8-10) kuului 38,7 \% tiloista, mutta vuonna 2005 niihin kuului enää 23,2 \% yrityksistä.

Siirtymän luokasta toiseen eivät kuitenkaan ole olleet erityisen suuria. Riskiluokista yleisin oli vuonna 2000 luokka 8 ja vuonna 2005 hiukan suurempaa riskiä osoittava luokka 7. Aineiston tilojen jakautuminen riskiluokkiin esitetään kuviossa 3.

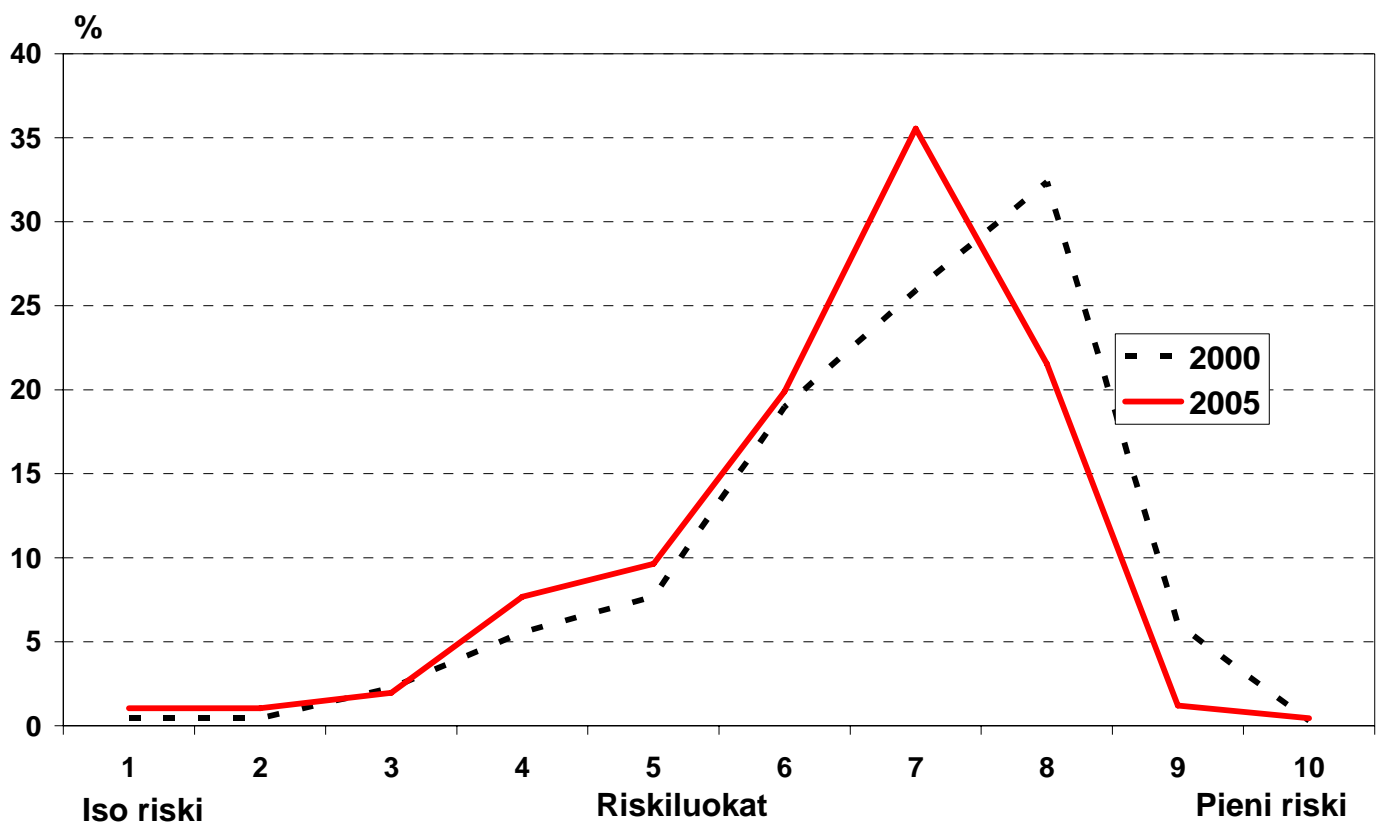

Kuvio 3. Maatilojen jakautuminen riskiluokkiin vuosina 2000 ja 2005

Tilakohtaisesti tarkasteltuna huomataan, että $43 \%$ tiloista on siirtynyt vuonna 2005 suurempaa riskiä osoittavaan riskiluokkaan verrattuna vuoteen 2000 , kun $38 \%$ on pysynyt samassa luokassa ja 19 \% siirtynyt pienempää riskiä osoittavaan luokkaan.

Riskiluokkatekijään ja siten myös riskiluokkaan vaikuttavia tekijöitä selvitettiin regressiomallinnuksen avulla. Regressiomallissa selitettiin riskiluokkatekijän suuruutta useilla yrityksen tulos- ja taselaskelmiin sekä myös tuotantoprosessiin (rysato) liittyvillä tekijöillä. Tämän lisäksi malliin sisälly- 
tettiin tuotantosuunittaisia dummy -muuttujia sekä vuosi -dummy. Regressiomallin tulokset esitetään taulukossa 1.

Maatalousyrityksen suuri velkamäärä ja sen myötä korkeat lainanhoitokulut kasvattavat odotusten mukaisesti tilan luottoriskiä. Myös korkeampi velan korkoprosentti lisää riskiä korkomenojen kasvun myötä. Osin syynä saattaa olla sekin, että kaikkea omaisuutta ei hyväksytä lainan vakuudeksi, mikä omalta osaltaan nostaa korkoprosenttia. Tilojen luottokelpoisuus on myös heikompi vuonna 2000 verrattuna vuoteen 2005. Tätä selittää ainakin tuotantopanoshintojen maataloustuotteiden tuottajahintoja nopeampi nousu.

Taulukko 1. Regressiomallin tulokset

$\begin{array}{ll}\text { Muuttuja } & \text { Parametrin Estimaatti } \\ \text { Vakio } & -0,04372 \\ \text { Viljelyala } & 0,00221^{* * *} \\ \text { Koneisiin ja rakennuksiin sitoutunut pääoma } & 0,00000113^{* * *} \\ \text { Korkoprosentti } & -0,55055 \\ \text { Velat } & -0,00000305^{* * *} \\ \text { rysato } & 0,00002977^{* *} \\ \text { D-viljatila } & -0,08647^{*} \\ \text { D-maitotila } & 0,0211 \\ \text { D-naudanlihatila } & 0,03943 \\ \text { D-sikatila } & 0,05497 \\ \text { D-vuosi } & -0,054790 \\ \text { R2 0,231 } & \text { F-testisuure 33,73*** }\end{array}$

Rahoitusriskit ovat alhaisemmat viljelyalaltaan sekä myös rakennus- ja konepääomaltaan suuremmilla yrityksillä. Näillä tuotannon kannattavuus on yleensä parempi kuin pienemmissä yrityksissä monista eri tekijöistä johtuen. Myös yrityksen vakavaraisuus on usein parempi., mikä näkyy suurempina vakuuksina. Vakuudet ovat sitä suuremmat ja korkoprosentti pääosin sitä pienempi, mitä vähemmän investointeja on rahoitettu vieraalla pääomalla.

Myös yrityksillä, joiden keskimääräinen satotaso (rysato) on suuri tilan, rahoitusriski on alhaisempi. Tämä johtuu osittain suurempien myyntitulojen ja yleensäkin yritysten paremman kannattavuuden vaikutuksista tilan taloudelliseen tilanteeseen. Keskisato-muuttujan voidaan ajatella kuvaavan myös yrittäjän yleistä ammattitaitoa.

Rahoitusriskit ovat olleet viljatiloilla suurempia kuin kotieläintiloilla. Tähän on vaikuttanut ainakin alhaiset viljan hinnat 2000-luvun ensimmäisen viiden vuoden aikana, mikä toisaalta samalla hillitsi kotieläintilojen rehukustannusten nousua. Viljan hintojen lasku on pienentänyt viljatilojen myyntituloja ja myös kannattavuus vajosi vuonna 2005 heikoimmilleen koko 2000-luvulla. Siten viljatilojen kannattavuuskehitys on ollut negatiivista ja kotieläintiloja heikompaa.

\section{Johtopäätökset}

Rahoitusriskit ovat kasvaneet jonkin verran. Tutkimus ei ota kantaa siihen, mihin riskiluokkaan kuuluvat tilat ovat luottokelvottomia. Vaikka alimmissa luottokelpoisuusluokissa olevien tilojen osuus onkin kasvanut hieman vuodesta 2000 vuoteen 2005, ei tutkimuksen perusteella voida sanoa, että tilojen, joilla on merkittäviä taloudellisia vaikeuksia, määrä olisi kasvanut merkittävästi.

Maatalouden rakennemuutos lisää tilojen velkamäärää ja siten kasvattaa rahoitusriskejä. Toisaalta suuremmilla tiloilla luottoriskit ovat usein alhaisemmat korkeamman kannattavuuden ja vakavaraisuuden takia. Ratkaisevaa tässä yhteydessä on siis se, miten paljon tilat pystyvät rahoittamaan investointejaan omalla pääomalla.

Erityisesti energiakustannukset ovat nousseet jyrkästi viime vuosina. Toisaalta viljojen hinnat ovat vuoteen 2005 jatkuneen laskun jälkeen kääntyneet nyt jyrkkään nousuun ja odotettavissa on, että ne jäänevät selvästi aiempaa korkeammalle tasolle. Tämä vahvistaa erityisesti viljatilojen taloudellista asemaa, kun taas kotieläintiloja rasittaa jatkossa energiakustannusten lisäksi myös viljojen hintojen 
noususta aiheutuva rehukustannusten nousu.

Jos maatilojen taloudellinen kehitys jatkuu vuosien 2000-2005 mukaisena ja samalla maatilojen rakennemuutos jatkuu, maatalouden rahoitusriskit lisääntyvät merkittävästi. Tässä tilanteessa pankit joutuvat soveltamaan nykyistä tiukempia kriteerejä lainojen myöntämisessä ja myös korkomarginaalit nykyisissä ja uusissa suuririskisissä luotoissa saattavat nousta huomattavasti, jolloin lainanhoitokustannukset nousevat merkittävästi. Pysyäkseen mukana kehityksessä tilojen on kuitenkin investoitava ja rahoitukseen tarvitaan vierasta pääomaa. Jos tilan taloudellisen tilanteen vuoksi luottoa ei ole mahdollista saada järkevillä ehdoilla, ei investointeja voida toteuttaa. Näin ollen luottoriskien kasvamisen ja rakennemuutoksen nopeuden välillä on selkeä yhteys.

\section{Kirjallisuus}

Escalante, C., Barry, P., Park, T. A. \& Demir, E. 2004. Farm-Level and Macroeconomic Determinants of Farm Credit Risk Migration Rates. Agric. Fin. Rev. 64:135-149.

Katchova, A. \& Barry, P. 2005. Credit Risk Models and Agricultural Lending. Am. J. of Agric. Econ. 87:194205.

Myyrä, S. ja Pietola, K. 2005. Velkojen keskittymiskehitys Suomen maatiloilla. MTT:n selvityksiä 92(2005). $35 \mathrm{~s}$.

Splett, N. S., Barry, P. J., Dixon, B. L. \& Ellinger, P. N. 1994. Valuation of Credit Risk in Agricultural Mortgages. Agric. Fin. Rev. 54:39-54.

Walraven, N. \& Barry, P. 2004. Bank Risk Ratings and the Pricing of Agricultural Loans. Agric. Fin. Rev. 64:107-118.

Zech, L. \& Pederson, G. 2004.Application of Credit Risk Models to Agricultural Lending. Agric. Fin. Rev. 64:91-106. 